\title{
Corrosion behavior of powder metallurgical stainless steels in urban and marine environments*
}

\author{
A. Bautista**, F. Velasco**, S. Guzmán**, D. de la Fuente****, F. Cayuela**** and \\ M. Morcillo***
}

\begin{abstract}
This work studies the development of corrosive attack on sintered components manufactured from AISI 316L and AISI 304L powders. The stainless steels were sintered in vacuum and in nitrogen-base atmosphere at 1,120 and $1,250^{\circ} \mathrm{C}$, and their corrosion resistance was then analyzed by electrochemical techniques and by atmospheric corrosion testing (two years) at urban and marine test sites. Images are shown of the morphology of the attack on the surface of the stainless steels and the development of this attack in the interior of the material.
\end{abstract}

Keywords

Corrosion. Stainless steels. Powder metallurgy. Sintering conditions. Marine atmosphere. Urban atmosphere.

\section{Comportamiento a corrosión de aceros inoxidables pulvimetalúrgicos en ambientes urbano y marino}

\begin{abstract}
Resumen Este trabajo estudia el desarrollo del proceso corrosivo en componentes sinterizados fabricados a partir de polvos de AISI 316L y AISI 304L. Los aceros inoxidables fueron sinterizados en vacío y en atmósfera base nitrógeno a 1.120 y $1.250{ }^{\circ} \mathrm{C}$ y, su resistencia a corrosión se ha analizado mediante técnicas electroquímicas y mediante ensayos de corrosión atmosférica (dos años) en ambientes urbano y marino. Se muestran imágenes de la morfología del ataque en la superficie de los aceros inoxidables y del desarrollo de este ataque en el interior del material.
\end{abstract}

Palabras clave Corrosión Aceros inoxidables. Pulvimetalurgia. Condiciones de sinterización. Atmósfera urbana. Atmósfera marina.

\section{INTRODUCTION}

Powder metallurgy (P/M) offers clear advantages in the manufacture of large quantities of pieces of complicated shapes and small size. Stainless steel powders are widely used for manufacturing $\mathrm{P} / \mathrm{M}$ components when corrosion resistance and aesthetic appearance are required to be above those of low-alloyed steels. Applications of P/M stainless steels span a variety of industries including aerospace, automotive, chemical processing, medical and leisure.

$\mathrm{P} / \mathrm{M}$ stainless steels are known to be less corrosion resistant that their wrought counterparts ${ }^{[1]}$. The corrosion behavior of $\mathrm{P} / \mathrm{M}$ stainless steels is simultaneously affected by several parameters:

\footnotetext{
* Trabajo recibido el día 8 de julio de 2005 y aceptado en su forma final el día 25 de enero de 2006.

** Departamento de Ciencia e Ingeniería de Materiales, Universidad Carlos III de Madrid, Avda. Universidad n 30, 28911-Leganés, Madrid. Spain.

$* * *$ Centro Nacional de Investigaciones Metalúrgicas (CSIC), Avda. Gregorio del Amo, 8, 28040-Madrid, Spain.

**** Escuela Técnica Superior de Naútica y Máquinas Navales, Portugalete, Vizcaya (Spain).
} 
- Interconnected porosity greatly increases the active surface exposed to corrosion ${ }^{[2-6]}$. The porosity of the sintered metals depends on the manufacturing parameters (compaction pressure, sintering temperature and sintering time). It has been suggested that pieces made from $\mathrm{P} / \mathrm{M}$ stainless steels with an average porosity may have a real surface about two orders of magnitude higher than the apparent surface $^{[7}$ and 8$]$.

- The morphology of the pores favors the formation of galvanic cells. Different aeration and/or lower pH can easily appear at the bottom of the pores, promoting the onset and development of pits ${ }^{[6,8}$ and 9].

- The nitrogen-base atmosphere, commonly used for sintering low-alloyed $\mathrm{P} / \mathrm{M}$ steels, favors the formation of Cr-rich precipitates, identified as $\mathrm{Cr}_{2} \mathrm{~N}^{[3]}$. These precipitates improve the mechanical properties of the materials, but reduce their corrosion resistance because of the implied decrease in the chromium content of the base metal ${ }^{[2}$ and 3$]$. When high-corrosion resistance is required, $\mathrm{P} / \mathrm{M}$ stainless steels are sintered in other atmospheres such as vacuum or pure $\mathrm{H}_{2}$.

Most of the literature dealing with the corrosion behavior of sintered stainless steel is based on results from simple immersion tests in very aggressive solutions (with high concentrations of chloride or hydrogen ions $)^{[4,6,10}$ and 11] and salt-spray cabinet testing ${ }^{[11-}$ 14]. There also exists authors that have evaluated the corrosion resistance of these materials by electrochemical d.c. techniques ${ }^{[1-3,5,8,9,15}$ and 16]. Given the high degree of contamination of the media used in previous studies, the results of the tests are often not discriminating enough to distinguish clearly the influence of the composition of the alloy or the sintering conditions on the corrosion behavior. Moreover, there is also the risk that the corrosion mechanism in an artificial environment may be different from that in a natural environment. The results of solution tests may also modify the response of the material because of factors such as the surface tension of the solution in the pores. However, up to now, there exits a lack of available information on the degradation rate or mechanism of these materials in any kind of natural environment, while other materials have been widely studied ${ }^{[17}$ and ${ }^{18]}$. The aim of this work is to check the information on the influence of the composition of the materials and of the sintering conditions on their corrosion resistance, using data from electrochemical tests, with their behavior in two very different natural atmospheres.

\section{EXPERIMENTAL}

Specimens of $\mathrm{P} / \mathrm{M}$ austenitic stainless steels were manufactured from two commercial water-atomized powders (AISI 304L and AISI 316L types) whose compositions are shown in Table I. Both stainless steels powders were uniaxially compacted at 700 $\mathrm{MPa}$, using zinc stearate as the die wall lubricant. The green compacts were sintered in two different atmospheres (vacuum and $95 \% \mathrm{~N}_{2}-5 \% \mathrm{H}_{2}$ ) at two different temperatures $\left(1,120\right.$ and $\left.1,250{ }^{\circ} \mathrm{C}\right)$. Heating and cooling rates were $5{ }^{\circ} \mathrm{C} / \mathrm{min}$. Samples of 8 materials with different characteristics were obtained. All the samples, of $8.3-8.4 \mathrm{~g}$, weight, had a surface of about $10 \times 55 \mathrm{~mm}$ and a thickness of $2.2-2.4 \mathrm{~mm}$.

Before subjecting the materials to atmospheric exposure, their relative density was measured by the water displacement method (ISO 2738). Their electrochemical behavior was characterized by polarization curves and the double loop electrochemical potentiokinetic reactivation test (DL-EPR). The polarization curves were carried out in $3.5 \% \mathrm{NaCl}$, sweeping the potential at $0.17 \mathrm{mV} / \mathrm{s}$, as used in wrought alloys $^{[19]}$. The DL-EPR test ${ }^{[16]}$ was carried out in 0.50 $\mathrm{M} \mathrm{H}_{2} \mathrm{SO}_{4}+0.01 \mathrm{M} \mathrm{KSCN}$, using a scan rate of 1.67 $\mathrm{mV} / \mathrm{s}$. In all the electrochemical measurements, a saturated calomel electrode was used as reference electrode and two graphite bars as counter-electrodes. The real (non-polished) surfaces of the steels were used as working electrodes to determine the influence of the characteristic morphology of the surface pores on the corrosion behavior.

The specimens used in this work were significantly smaller than the panels used in most of the atmospheric exposure programs, but the characteris-

Table I. Composition of the used powders

Tabla I.: Composición de los polvos usados

\begin{tabular}{lllllllll}
\hline & $\% \mathbf{C}$ & $\% \mathbf{C r}$ & $\% \mathbf{N i}$ & $\% \mathbf{M o}$ & $\% \mathbf{S i}$ & $\% \mathbf{M n}$ & $\% \mathrm{Cu}$ & $\% \mathrm{Fe}$ \\
\hline AISI 316L & 0.02 & 16.1 & 13.55 & 2.24 & 0.87 & - & 0.02 & bal. \\
AISI 304L & 0.02 & 18.1 & 11.00 & 0.01 & 0.8 & 0.1 & 0.02 & bal. \\
\hline
\end{tabular}




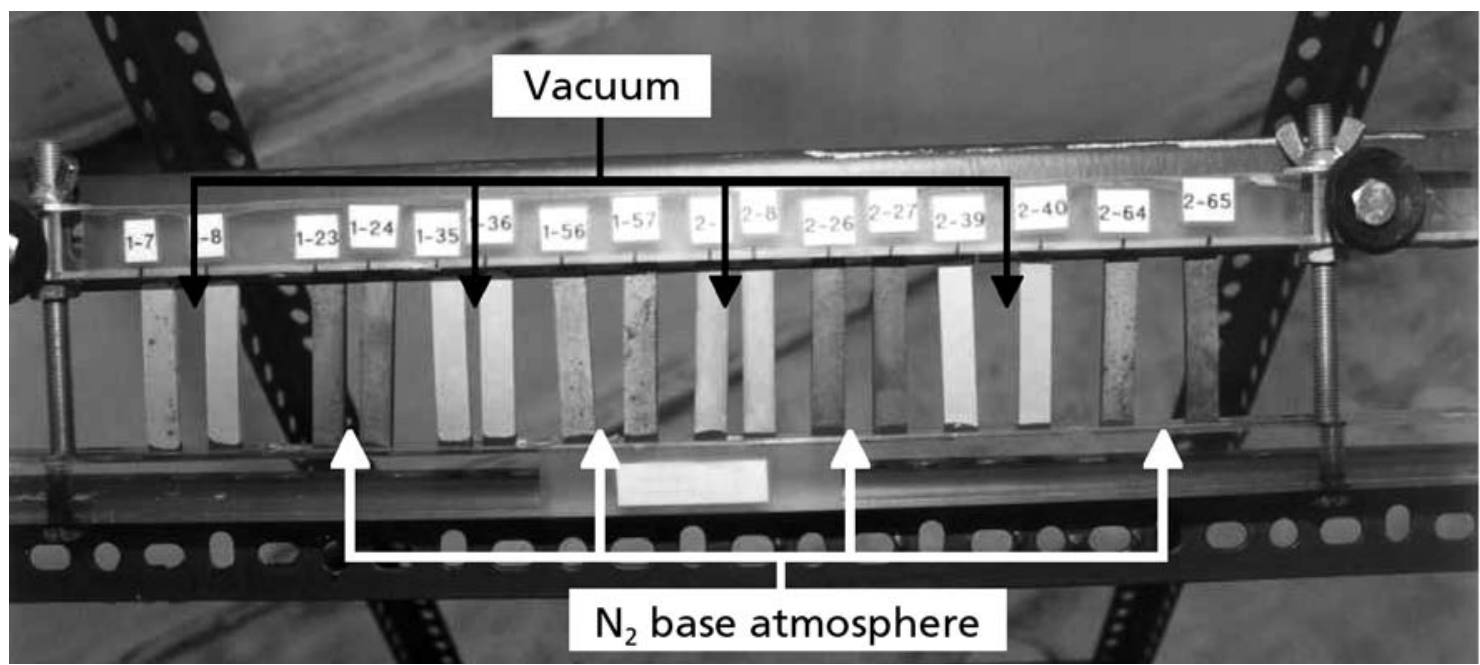

Figure 1. Specimen holder designed for the atmospheric exposure test of P/M materials and appearance of the materials after 2 weeks of exposure to marine environment.

Figura 1. Portamuestras diseñado para el ensayo de exposición atmosférica de los materiales P/M y aspecto de los materiales después de 2 semanas de exposición al ambiente marino.

tics of the processing method of the $\mathrm{P} / \mathrm{M}$ materials do not allow the manufacture of samples of great surface. The small dimensions of the specimens made it necessary to design a special system of fixation to the racks, as shown in figure 1. The use of methacrylate holders with shallow tracks into which the specimens were fixed, allowed a minimum loss of the surface available for study. The specimens were placed in the holders, their upper and lower edges protected with a suitable organic coating to avoid possible corrosion problems due to the crevice between the holders and the specimens.

The holders were fixed in racks in two different natural environments: an urban environment (Madrid, Spain), and a marine one (Portugalete, Vizcaya, Spain), whose main characteristics are shown in

Table II. Characteristics of the natural environments

Tabla II. Características de los ambientes naturales

\begin{tabular}{lcc}
\hline & Madrid & Portugalete \\
\hline $\begin{array}{l}\text { Time of Wetness (annual } \\
\text { fraction) } \\
\text { Chloride deposition rate } \\
\left(\mathrm{mg} \cdot \mathrm{m}^{-2} \cdot \mathrm{d}^{-1}\right)\end{array}$ & 0.155 & 0.494 \\
$\begin{array}{l}\text { Sulphate deposition rate } \\
\left(\mathrm{mg} \cdot \mathrm{m}^{-2} \cdot \mathrm{d}^{-1}\right)\end{array}$ & 0.9 & 39 \\
$\begin{array}{l}\text { Corrosivity Category }( \\
\text { according to ISO 9223) } \\
\begin{array}{l}\text { Corrosion rate of the steel } \\
\left(\mu \mathrm{m} \cdot \mathrm{y}^{-1}\right)\end{array}\end{array}$ & 36.6 & 91 \\
\hline
\end{tabular}

Table II. The exposure angle was $45^{\circ}$ to the horizontal. The intensity of the corrosion was evaluated visually on the upper-facing surface (that always coincided with the punch surface during compaction). The morphology of the attack in cross sections was studied by scanning electron microscopy (SEM) and the composition of the oxide by semiquantitative electron dispersive X-Ray spectroscopy (EDS).

\section{RESULTS}

Figure 2 shows the sintering densities (relative to the densities of wrought stainless steels of the same com-

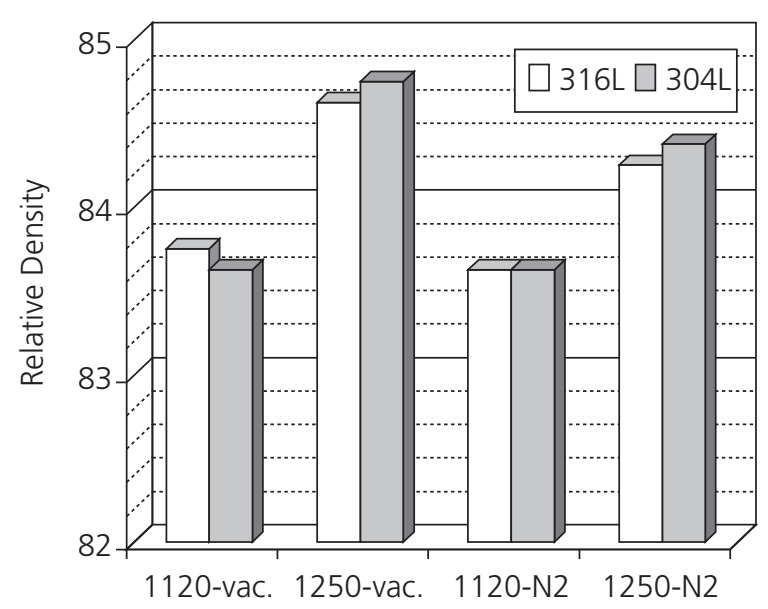

Figure 2. Relative density of the sintered stainless steels.

Figura 2. Densidad relativa de los aceros inoxidables sinterizados. 


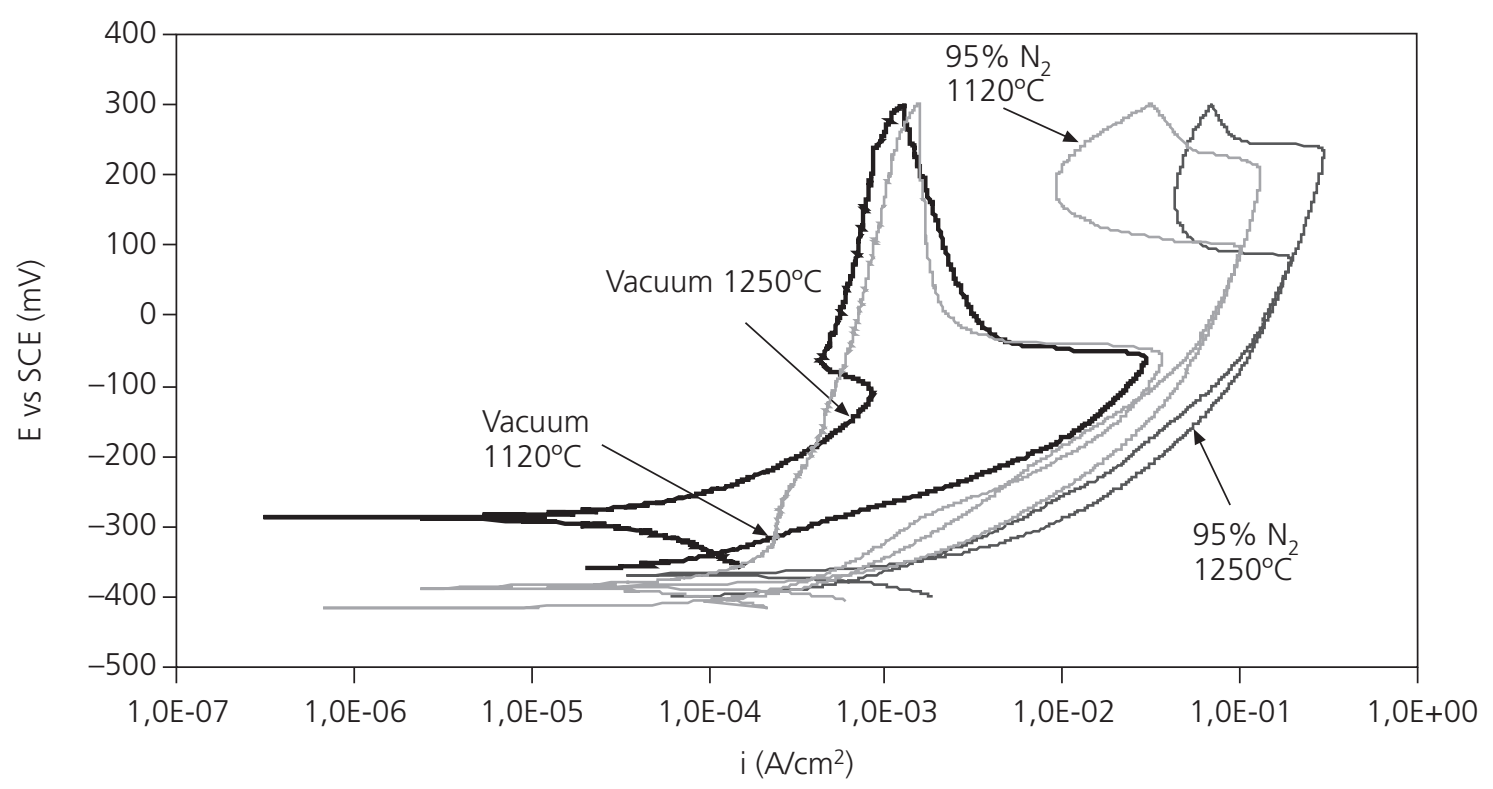

Figure 3. DL-EPR test results of $316 \mathrm{~L}$ stainless steel sintered in different conditions.

Figura 3. Resultados del ensayo de DL-EPR del acero inoxidable $316 \mathrm{~L}$ sinterizado en diferentes condiciones.

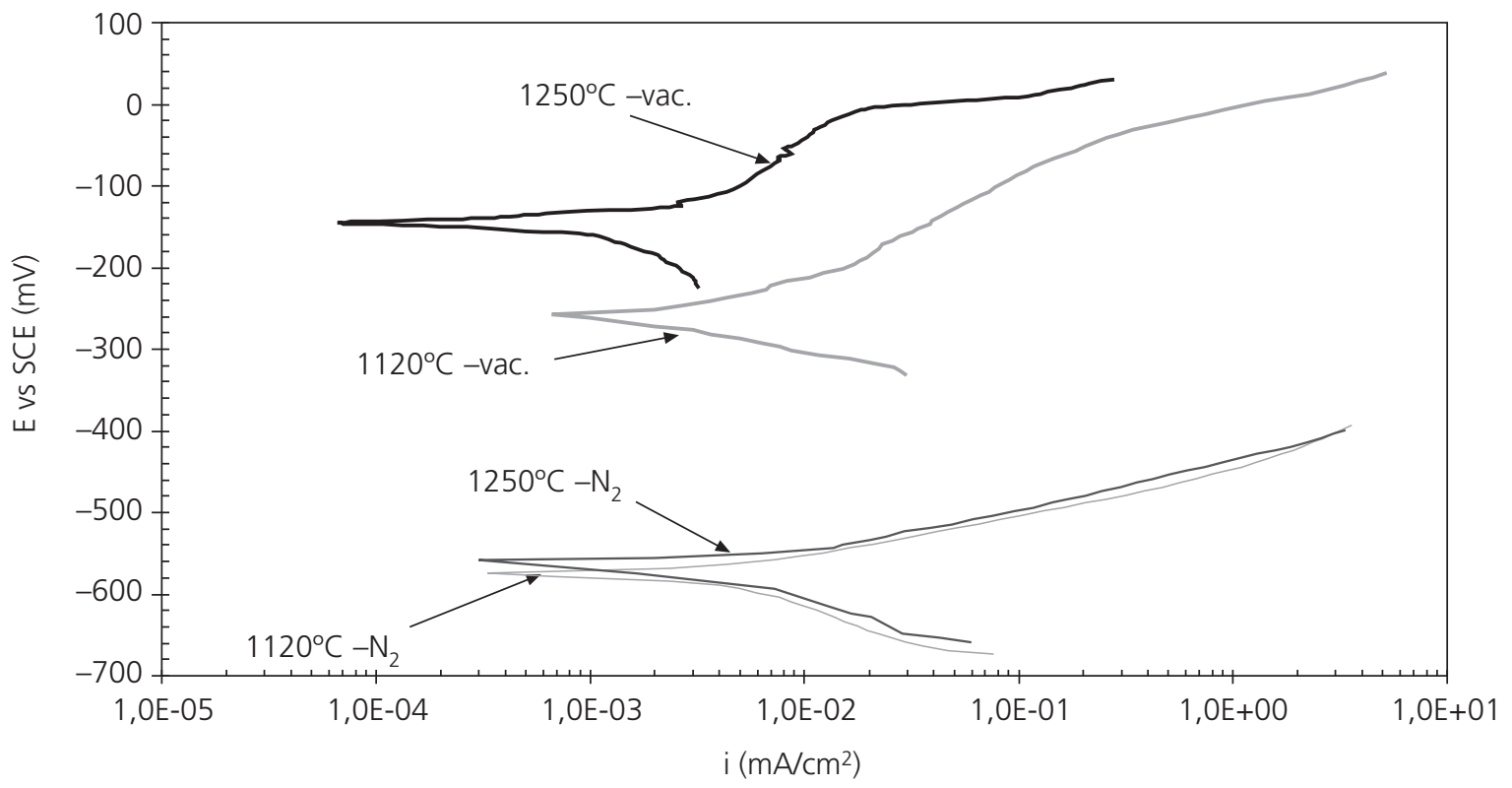

Figure 4. Polarisation curves in chloride media of $304 \mathrm{~L}$ stainless steel sintered in different conditions.

Figura 4. Curvas de polarización en cloruros del acero inoxidable 304L sinterizado en diferentes condiciones.

position) of the studied $\mathrm{P} / \mathrm{M}$ stainless steels. No differences were found between AISI 316L and AISI 304L sintered in the same conditions. The nature of the studied sintering atmospheres not seems to have a significant influence on the density. With a given compaction pressure, the density increased when the sintering temperature was higher. These data show that stainless steels sintered at $1,250{ }^{\circ} \mathrm{C}$ had porosities of $15.4-15.7$ $\%$, and those sintered at $1,120{ }^{\circ} \mathrm{C}$ of about $16.3 \%$.
Some typical results obtained from the electrochemical characterization of the influence of the sintering parameters on the corrosion behavior of the stainless steels are shown in Figs. 3 and 4. DL-EPR tests revealed that the degree of susceptibility to intergranular corrosion of materials sintered in $\mathrm{N}_{2}$ base atmosphere was very high, with identical results in 304L and 316L stainless steels sintered in $95 \% \mathrm{~N}_{2}$. The intensity of the reactivation peak $\left(\mathrm{i}_{\mathrm{r}}\right)$ 

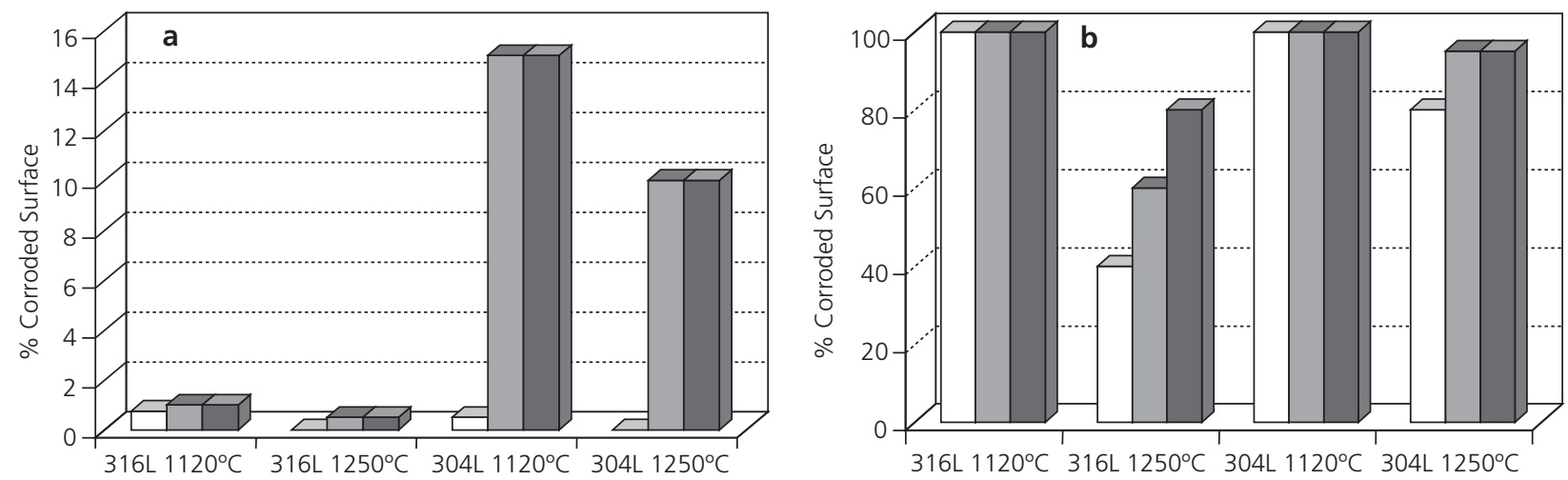

$$
\square 15 \text { days } \square 1 \text { year } \square 2 \text { years }
$$

Figure 5. Percentage of corroded surface of the sintered specimens after $15 d, 1$ and 2 years of exposure to marine environment. (a) Vacuum sintered stainless steels. (b) $95 \%-\mathrm{N}_{2}$ sintered stainless steels.

Figura 5. Porcentaje de superficie corroída de las muestras sinterizadas después de 15 d, 1 y 2 años de exposición al ambiente marino. (a) Aceros inoxidables sinterizados en vacío. (b) Aceros inoxidables sinterizados en $95 \%-\mathrm{N}_{2}$.

was slightly closer to that of the activation peak $\left(i_{a}\right)$ in steels sintered at $1,120^{\circ} \mathrm{C}\left(\mathrm{i}_{\mathrm{r}} / \mathrm{i}_{\mathrm{a}}=0.95\right)$ than in the stainless steels sintered in $95 \% \mathrm{~N}_{2}$ at higher temperature $\left(i_{1} / i_{a}=0.75\right)$ (Fig. 3). On the other hand, 316L stainless steels sintered in vacuum at $1,120{ }^{\circ} \mathrm{C}$ exhibited $\mathrm{i}_{\mathrm{r}} / \mathrm{i}_{\mathrm{a}}=6.6 \cdot 10^{-3}$ while the $\mathrm{i}_{\mathrm{r}} / \mathrm{i}_{\mathrm{a}}$ of $316 \mathrm{~L}$ sintered at $1,250^{\circ} \mathrm{C}$ in vacuum was $3.3 \cdot 10^{-2}$. The DL-EPR curves of $304 \mathrm{~L}$ vacuum sintered stainless steels were very similar to those of $316 \mathrm{~L}$, but the $\mathrm{i}_{\mathrm{r}} / \mathrm{i}_{\mathrm{a}}$ values were somewhat higher.

The polarization curves of $\mathrm{N}_{2}$-sintered stainless steels were always very similar, independently of the sintering temperature and the composition of the base material (Fig. 4). Polarization curves of vacuum sintered stainless steels revealed more noble corrosion potentials and lower corrosion rates than those of steels sintered in $\mathrm{N}_{2}$ base atmosphere. Polarization tests of vacuum-sintered steels gave some dispersion of results when the study was carried out on the real surface of the steels. However, a significant improvement of the corrosion behavior was detected when the sintering temperature in vacuum was raised from 1,120 to $1,250{ }^{\circ} \mathrm{C}$. The length of the pseudo-passive zone of the curve is a few milivolts higher in $316 \mathrm{~L}$ than in $304 \mathrm{~L}$ sintered at the same temperature.

The intensity of the attack on the different materials after different times of exposure in natural environments was evaluated visually. Results of exposure in the marine environment are shown in figure 5 and those of exposure in urban environment in figure 6. As expected, the marine environment proved to be more aggressive than the urban environment for all the materials, and very important differences in the corrosion resistance of the stainless steels were found depending on their sintering atmosphere.

Corrosion appeared very fast in the $304 \mathrm{~L}$ and $316 \mathrm{~L}$ stainless steels sintered in vacuum at $1,120{ }^{\circ} \mathrm{C}$ in the marine site, and pits were large enough to be visually detected after $15 \mathrm{~d}$ (Fig. 5a). Inspections during the first weeks of exposure proved that the sintering temperature in vacuum seemed to be more determinant than the presence of Mo in 316L in delaying the onset of the attack. However, after 1 year of exposure, pitting corrosion in vacuum sintered specimens was conditioned much more by the type of base metal than by the sintering temperature: the 316L specimens proved to be much more resistant to long-term corrosion than the $304 \mathrm{~L}$ specimens in the marine environment. On the other hand, 316L had not been more corrosion resistant than $304 \mathrm{~L}$ in urban environment, though the beneficial effect of increasing the sintering temperature was also detected (Fig. 6a).

The development of the attack was always very fast on $\mathrm{N}_{2}$-sintered materials. Corrosion products tended to appear in the bottom of the numerous pores on the surface of the materials, and the attack spread easily over all the surface in aggressive environments (Fig. 1). When sintering was done at $1,120^{\circ} \mathrm{C}$, corrosion products covered all the surface after only $15 \mathrm{~d}$ of exposure in marine environment (Fig. 5b). In urban environments the rate of the attack was slower, but after 1 year of exposure the specimens were severely corroded (Fig. 6b). During the second year of exposure, the rate of the attack seemed to slow down because of the presence of the corrosion products in nitrogen sintered specimens as well as in vacuum sintered specimens (Figs. 5 and 6). 

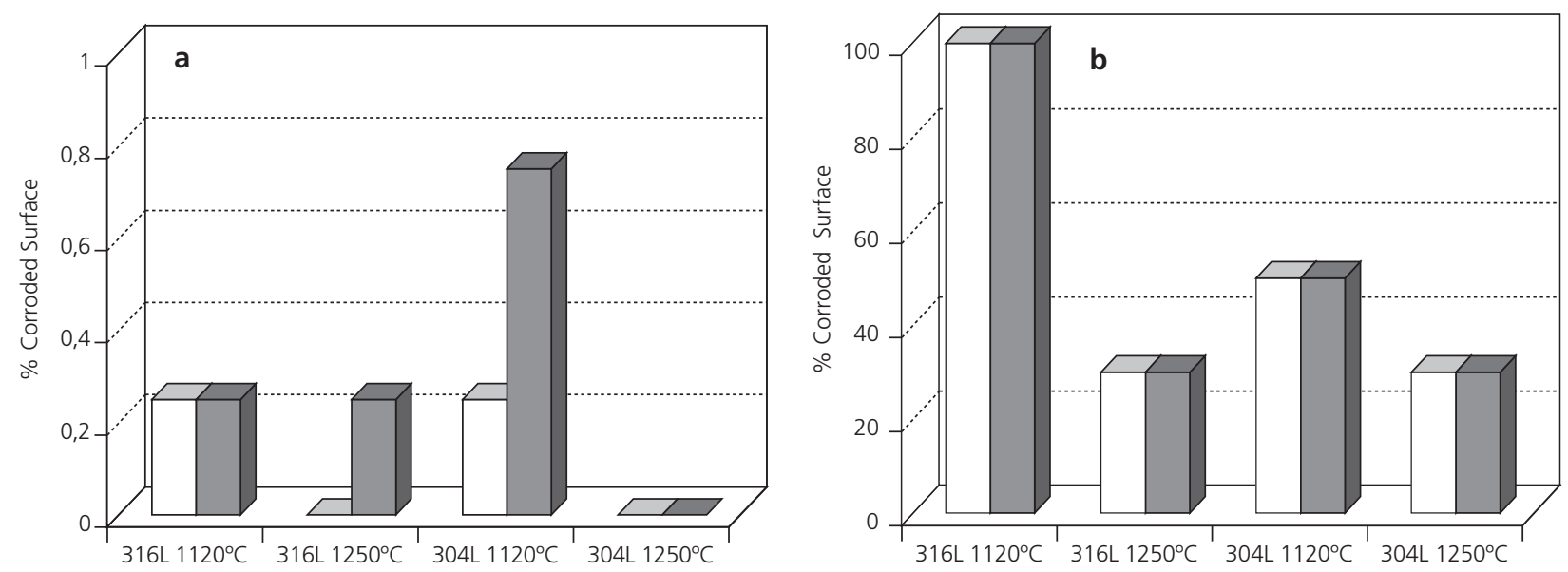

$$
\square 1 \text { year } \square 2 \text { years }
$$

Figure 6. Percentage of corroded surface of the sintered specimens after 1 and 2 years of exposure to urban environment. (a) Vacuum sintered stainless steels. (b) $95 \%-\mathrm{N}_{2}$ sintered stainless steels.

Figura 6. Porcentaje de superficie corroída de las muestras sinterizadas después de 1 y 2 años de exposición al ambiente urbano. (a) Aceros inoxidables sinterizados en vacío. (b) Aceros inoxidables sinterizados en $95 \%-\mathrm{N}_{2}$.

Figures 7 and 8 show to what extent the amount and the morphology of the attack were dependent on the sintering temperature and sintering atmosphere. After 2 years of exposure in marine environments, vacuum sintered stainless steels suffer pitting corrosion, while on those sintered in $\mathrm{N}_{2}$-base atmosphere the corrosion tends to be generalized, especially in those materials sintered at low temperatures (Fig. 7). After exposure to Madrid atmosphere, 304L specimens sintered in vacuum at $1,250{ }^{\circ} \mathrm{C}$ showed no sign of corrosion, while some small pits appeared in $304 \mathrm{~L}$ sintered in vacuum at $1,120{ }^{\circ} \mathrm{C}$. In $\mathrm{N}_{2}$ sintered specimens, corrosion was generalized, with indications of points where the attack was more intense. These points of intense attack coincided with the largest pores on the surface of the material.

SEM observations of the cross-sections of the specimens after exposure complemented the visual observation of the attack on the surface and offered important information about its development inside the inner pores. In vacuum sintered steels, after 1 year of exposure in marine or urban environment, no signs of attack were detected in any of the sections. In specimens exposed for 2 years to the urban atmosphere, most of the sections exhibited only the porosity characteristic of these materials. Very rarely, the presence of small quantities of oxide was observed at the bottom of a pore (Fig. 9). EDS semiquantitative analysis revealed that this oxide comprises only $\mathrm{Fe}$ and $\mathrm{O}$. The presence of oxides in the pores was more usual in specimens exposed for two years to marine environment and some oxides were easily

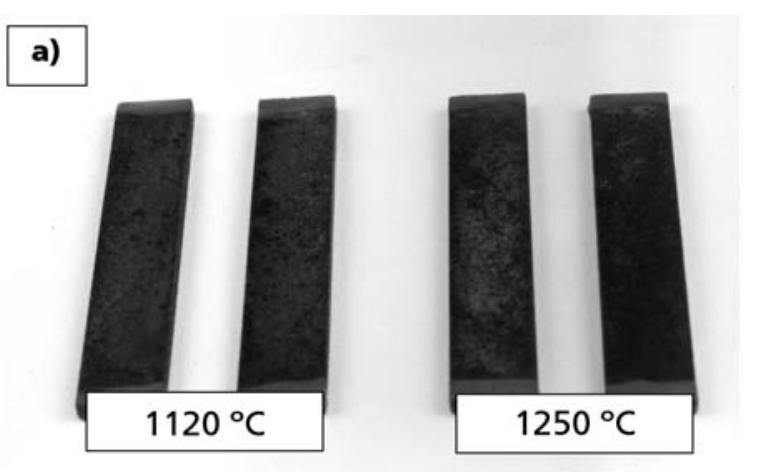

b)
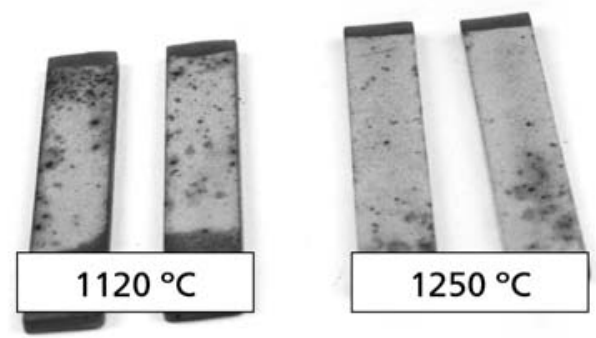

Figure 7. Visual appearance of sintered 304L stainless steels after 2 years of exposure to marine environment: (a) Specimens sintered in a $\mathrm{N}_{2}$-base atmosphere; (b) Specimens sintered in vacuum.

Figura 7. Aspecto visual de aceros inoxidables $304 \mathrm{~L}$ sinterizados después de 2 años de exposición al ambiente marino: (a) Muestras sinterizadas en atmósfera base $\mathrm{N}_{2}$; (b) Muestras sinterizadas en vacío. 


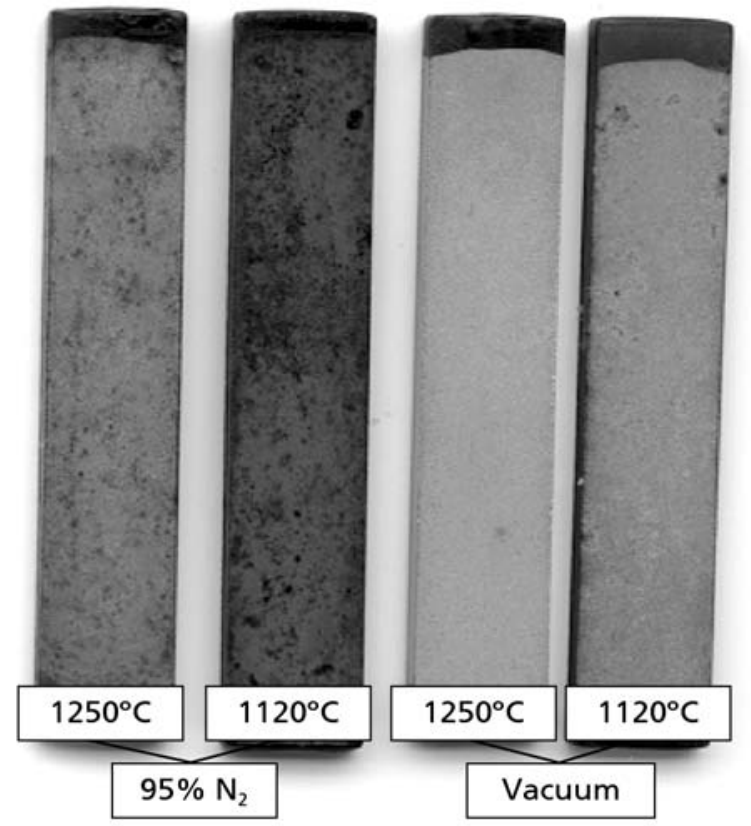

Figure 8. Visual appearance of the four different types of sintered 304L stainless steels after 2 years of exposure to urban environment.

Figura 8. Aspecto visual de cuatro tipos diferentes de aceros inoxidables 304L sinterizados después de 2 años de

seen in $304 \mathrm{~L}$ sintered at $1,120{ }^{\circ} \mathrm{C}$ (Fig. 9b). The oxides appeared always in the large pores located on or near the surface of the material.

On stainless steels sintered in $\mathrm{N}_{2}$ base atmosphere at $1,120{ }^{\circ} \mathrm{C}$ and exposed for 1 year to urban environment, a layer of oxide already covered the surface. An important amount of oxide was observed in the inner pores of the materials. Though the attack was more intense near the surface, corrosion products were detected inside the stainless steels up to distances as deep as $1 \mathrm{~mm}$. The micrography in figure 10a shows the importance of the internal oxidation in stainless steels sintered in $95 \% \mathrm{~N}_{2}$ at $1,120{ }^{\circ} \mathrm{C}$ and the formation of oxides in the inner pores. Moreover, severe intergranular corrosion was observed all over the material. In figure $10 \mathrm{~b}$, with higher magnification, the $\mathrm{Cr}_{2} \mathrm{~N}$ responsible for the intergranular attack, is clearly visible as light grey precipitates mainly located on the grain boundaries of the material. The great thickness of the external oxide formed on these materials after exposure in both environments allow to observe the multiple-layer structure of the oxide (Fig. 10b). Oxide sub-layers in lighter color comprised $\mathrm{Fe}$ and $\mathrm{O}$, while darker oxide sub-layers comprised $\mathrm{Fe}, \mathrm{Cr}$ and $\mathrm{O}$.

In stainless steels sintered in $\mathrm{N}_{2}$ base atmosphere at $1,250{ }^{\circ} \mathrm{C}$, the intensity of the oxidation was much lower then that in stainless steels sintered in $\mathrm{N}_{2}$ at lower temperature and exposed to the same environments (Fig. 11). The external layer of oxide was difficult to observe in most sections of the materials exposed to urban environments, and internal oxides appeared only in some pores located mainly near the surface or large pores at certain distance of the surface. The presence of oxides in the inner pores is shown with circles in figure 11a. In specimens exposed to marine environment, the external oxide layers were easily observed and they had a structure of multiple layers formed by Fe oxide and a mixed FeCr oxide (Fig. 11b).

It can also be seen in figure $11 \mathrm{~b}$, that has higher magnification, shows that the precipitation of chro-
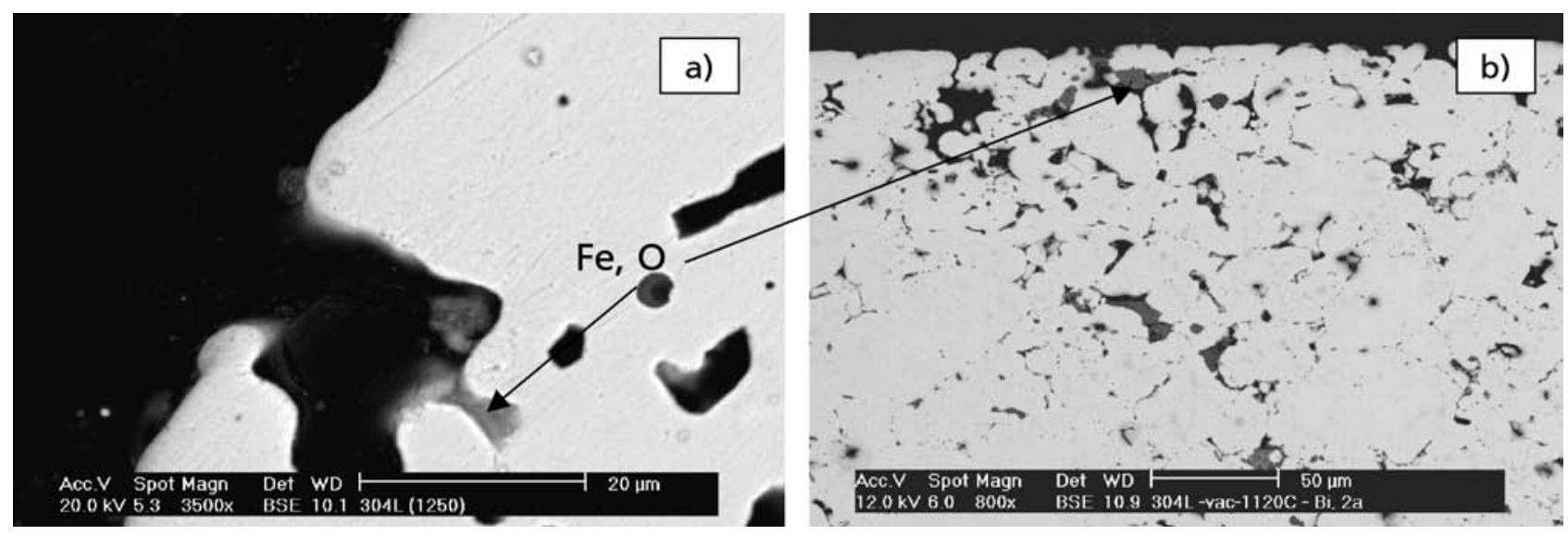

Figure 9. Cross-sectional SEM images of vacuum sintered stainless steels. (a) 304L type sintered at 1,250 ${ }^{\circ} \mathrm{C}$ and exposed for 2 years to urban environment. (b) $304 \mathrm{~L}$ type sintered at $1,120^{\circ} \mathrm{C}$ and exposed for 2 years to marine environment.

Figura 9. Imágenes de MEB de la sección transversal de los aceros inoxidables sinterizados en vacío. (a) 304L sinterizado a $1.250^{\circ} \mathrm{C}$ y expuesto durante 2 años a un ambiente urbano. (b) $304 \mathrm{~L}$ sinterizado a $1.120^{\circ} \mathrm{C}$ y expuesto durante 2 años a un ambiente marino. 

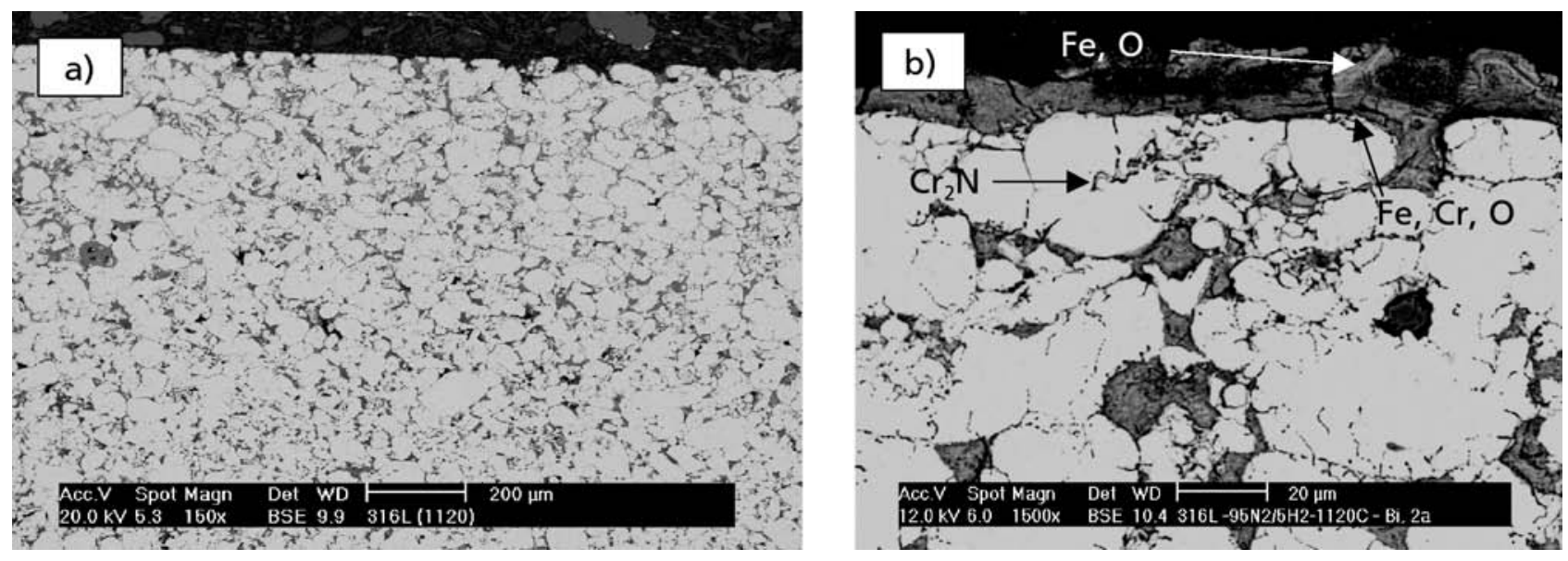

Figure 10. Cross-sectional SEM images of stainless steels sintered in $\mathrm{N}_{2}$-based atmospheres at $1,120^{\circ} \mathrm{C}$. (a) $316 \mathrm{~L}$ type exposed for 2 years to urban atmosphere. (b) 304L type exposed for 2 years to marine environment.

Figura 10. Imágenes de MEB de la sección transversal de los aceros inoxidables sinterizados en atmósfera base $\mathrm{N}_{2}$ a $1,120{ }^{\circ} \mathrm{C}$. (a) $316 \mathrm{~L}$ expuesto durante 2 años a una atmósfera urbana. (b) $304 \mathrm{~L}$ expuesto durante 2 años a un ambiente marino.
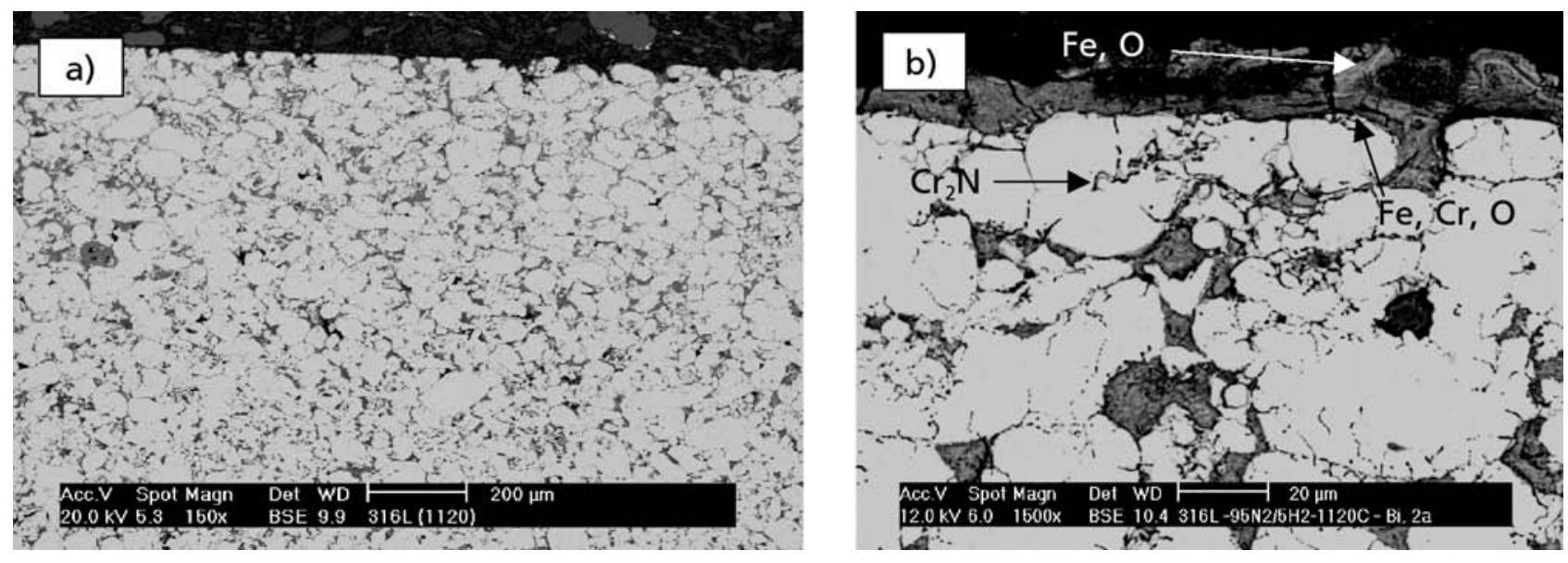

Figure 11. Cross-sectional SEM images of stainless steels sintered in $\mathrm{N}_{2}$-based atmospheres at $1,250{ }^{\circ} \mathrm{C}$. (a) $316 \mathrm{~L}$ type exposed for 2 years to urban atmosphere. (b) 304L type exposed for 2 years to marine environment

Figura 11. Imágenes de MEB de la sección transversal de los aceros inoxidables sinterizados en atmósfera base $\mathrm{N}_{2}$ a $1.250{ }^{\circ} \mathrm{C}$. (a) $316 \mathrm{~L}$ expuesto durante 2 años a una atmósfera urbana. (b) $304 \mathrm{~L}$ expuesto durante 2 años a un ambiente marino.

mium nitrides during sintering at $1,250{ }^{\circ} \mathrm{C}$ occurred in the form of perlitic colonies, instead of at the grain boundaries. The morphology of the distribution of precipitates is homogeneous in all the thickness of the studied stainless steels. Specimens sintered in $95 \% \mathrm{~N}_{2}$ at $1,250{ }^{\circ} \mathrm{C}$ proved to be susceptible (depending on the aggressiveness of the environment) to develop an attack induced by the presence of $\mathrm{Cr}_{2} \mathrm{~N}$ that is not intergranular but "intragranular". Intragranular attack did not appear in any of the 304L and 316L stainless steels sintered at 1,250 ${ }^{\circ} \mathrm{C}$ and exposed to urban environment. In specimens exposed to marine environment, after 1 year of exposure, the onset of an intragranular attack was detected in some isolated regions very close to the surface of the materials. It should be stressed that the intensity of this kind of attack increases appreciablely during the second year of exposure (Fig. 11b) but it never affects the inner regions of the steel. With the same stainless steel composition and the same exposure time, 304L specimens proved to be more susceptible to intragranular corrosion in marine environments than were the 316L specimens.

\section{DISCUSSION}

Of the four factors influencing the corrosion behavior considered in this study of atmospheric corrosion 
(sintering atmosphere, sintering temperature, composition of the austenitic stainless steels and aggressiveness of the natural environment), the sintering atmosphere proved to be the most important (Figs. 5 and 6). In specimens sintered in $\mathrm{N}_{2}$ base atmosphere, the attack starts soon (Fig. 1) and tended to affect the whole surface of the material (Figs. 7 and 8). The stainless steel sintered in $\mathrm{N}_{2}$, from the point of view of corrosion, behaves like a low-alloyed steel. The higher intensity of the attack in the pores is probably due to the fact that its morphology favors the condensation and retention of water from the environment and hence the development of corrosion. On vacuum sintered stainless steel, an acceptable passive layer is formed but it tends to be broken at the bottom of certain pores whose morphology make then more prone to corrosion (Fig. 9a). The marked decrease in the corrosion resistance due to the precipitation of $\mathrm{Cr}_{2} \mathrm{~N}$ when sintering has been carried out in the presence of $\mathrm{N}_{2}$ agree with the results obtained in DL-EPR (Fig. 3) and polarization (Fig. 4) tests.

The degree of porosity of the stainless steel depends on their sintering temperature. The results in figure 2 demonstrate that the eight steels of the study are porous enough to assume that most of their porosity was interconnected ${ }^{[20]}$. However, the relatively small decrease of the porosity due to the increase of the sintering temperature from 1,120 to $1,250{ }^{\circ} \mathrm{C}$ (about $1 \%$ ) is able to improve slightly the resistance to pitting corrosion of vacuum sintered specimens (Figs. $5 \mathrm{a}$ and $6 \mathrm{a}$ ). It seems that the more open surface porosity of stainless steels sintered in vacuum at $1,120{ }^{\circ} \mathrm{C}$ favors the formation of pits (see results after $15 \mathrm{~d}$ of exposure in figure $5 \mathrm{a}$ ), though the long-term corrosion rate may be strongly dependent on other factors such the composition of the base metal. The influence of the sintering temperature on the corrosion behavior in natural environments of vacuum sintered specimens coincides with the information obtained form the polarization curves (Fig. 4), but is contrary to the results of DL-EPR tests (Fig. 5). To understand this fact, it should be borne in mind that DL-EPR test are designed to study the susceptibility to intergranular corrosion, and vacuum sintered specimens do not suffer this kind of attack (Fig. 9b). The higher intensity of the reactivation peak in specimens sintered at $1,250^{\circ} \mathrm{C}$ may be due to fact that a slight loss of $\mathrm{Cr}$ from vaporization can occur during vacuum sintering and the probability of $\mathrm{Cr}$ vaporization increases with the higher sintering temperature. The results of atmospheric exposure confirm that the decrease of porosity at a higher sintering temperate has much more influence on the corrosion behavior than this probable small Cr loss.

The influence of the sintering temperature is also very important in stainless steels sintered in $\mathrm{N}_{2}$ base atmosphere. The amount and distribution of the for- med $\mathrm{Cr}_{2} \mathrm{~N}$ precipitates varies a lot with the sintering temperature (Figs. 10b and 11b) and strongly condition the intensity and morphology of the attack on the surface and inside the materials. The lesser corrosion of the stainless steels sintered in nitrogenbase atmospheres at $1,250{ }^{\circ} \mathrm{C}$ as compared to those sintered at $1,120{ }^{\circ} \mathrm{C}$ (Figs. 5 and 6) can be only partly explained by their lower porosity (Fig. 2). It is known that the solubility of $\mathrm{N}_{2}$ in austenitic matrixes and the formation of chromium nitrides are maximum at temperatures around $1,050{ }^{\circ} \mathrm{C}$, and the percentage of $\mathrm{N}_{2}$ absorbed declines as temperature rises $^{[21]}$. The lower free-Cr concentration in the base metal explains the higher attack on the surface in natural environments of specimens sintered in $95 \%$ $\mathrm{N}_{2}$ at $1,120{ }^{\circ} \mathrm{C}$ (Figs. 5b and 6b) and their slightly worse results in the DL-EPR test (Fig. 3). The corrosion in the inner regions of the materials is strongly conditioned by the distribution of the Cr precipitates, which varies with the sintering temperature. The location of the $\mathrm{Cr}_{2} \mathrm{~N}$ at the grain boundaries in steels sintered at $1,120{ }^{\circ} \mathrm{C}$ favors an intense intergranular corrosion (Fig. 10), because oxygen can diffuse easily through the chain of interconnected pores that usually coincides with the grain boundaries of the material. When the $\mathrm{Cr}_{2} \mathrm{~N}$ is precipitated with a perlitic structure, corrosion induced by the precipitates does not develop in moderately aggressive environments (Fig. 11a) and only appears in highly aggressive environments after moderately long periods of exposure (Fig. 11b). This was probably due to the difficulty for oxygen to diffuse to the Cr-poor areas close to the precipitates when these were located in the dense part of the material.

The nature of the austenitic powders $304 \mathrm{~L}$ or 316L types) make no significant difference in urban environments, but the presence of Mo has proved to be effective in slowing down the development of pitting corrosion in vacuum sintered steels during their exposure to marine environments (Fig. 5). This coincides with the results of the polarization curves performed in highly chloride contaminated solution (Fig. 4). The higher corrosive attack in $304 \mathrm{~L}$ specimens sintered in $\mathrm{N}_{2}$ base atmosphere, as compared to the attack in 316L specimens sintered in the same conditions, has not been foreseen by the polarization curves in chloride media but fits the prediction of the DL-EPR tests.

\section{CONCLUSIONS}

The work presented in this paper demonstrates, with results obtained in natural environments, the adverse influence of porosity on the corrosion resistance of powder metallurgical stainless steels and 
shows images of its morphology in natural environments. It validates several important conclusions about the influence of the sintering parameters on the corrosion behavior of stainless steels:

Vacuum sintered stainless steels have proved to be much more corrosion resistant than those sintered in nitrogen-base atmosphere, which actively corrode in any environment.

Materials sintered at $1,250{ }^{\circ} \mathrm{C}$ always behave better than those sintered at $1,120{ }^{\circ} \mathrm{C}$ in the same atmosphere. Minor porosity and, in materials sintered in nitrogen-base atmosphere, also the minor chromium nitride precipitation, explain this fact.

The development of corrosion inside stainless steels sintered in $\mathrm{N}_{2}$ base atmosphere is strongly conditioned by the distribution of the $\mathrm{Cr}_{2} \mathrm{~N}$ precipitates. A perlitic distribution partially hinders the attack.

Vacuum sintered 316L are less prone to pitting corrosion than vacuum sintered 304L in marine environment. However, there is no difference between the two austenitic stainless steels when chlorides are not responsible for the onset of the attack.

\section{REFERENCES}

[1] E. Otero, A. Pardo, E. Sáenz, M. V. Utrilla AND P. Hierro, Corros. Sci. 38 (1996) $1485-$ 1493.

[2] L. Feddrizzi, A. Molinari, F. Deflorian, A. TiZIANI AND P. L. BONORA, Br. Corros. J. 26 (1991) $46-50$

[3] E. Angelini, P. Bianco, F. Rosalbino, M. Rosso AND G. SCAVINO, Werks. Korr. 45 (1994) 392-401.

[4] F. Velasco, J. M. Ruiz-Román, J. M. Torralba AND J. M. Ruiz-Prieto, Br. Corros. J. 31 (1996) 295-299.

[5] L. Fedrizzi, J. Crousier, P. L. Bonora And J. P. Crousier, Werks. Korr. 42 (1991) 403-409.

[6] F. Velasco, J. M. Torralba, J. M. Ruiz-Román, L. E. GARCÍA-CAmbronero AND J. M. Ruiz-Prieto, Int. J. Powder Metall. 31 (1995) 309-315.

[7] A. Bautista, F. Velasco, M. Campos, M. E. Rabanal and J. M. Torralba, Oxid. Met. 59 (2003) 373-393.
[8] T. Raghu, S. N. Malhotra and P. RamakrishNAN, Corrosion 45 (1989) 698-704.

[9] T. Raghu, S. N. Malhotra and P. RamakrishNAN, Br. Corros. J. 23 (1988) 109-116.

[10] E. Klar And P. K. SAmal, Powder Metals: Corrosion Test and Standards Manual, R. Baboian (Ed.), American Society for Testing and Materials, Philadelphia, USA, 1995, pp. 551557.

[11] B. SHAw, Powder Metals Technologies and Applications, Ed. ASM Handbook, vol. 7, ASM International, Materials Park, USA, 1998, pp. 978-1005.

[12] F. Velasco, L. F. Tejada, W. M. Lima, R. Marcé, J. A. Bas and J. M. Torralba, Key Eng. Mater. 189-191 (2001) 346-351.

[13] J. Abenojar, F. Velasco, J. M. Torralba, J. A. Bas, J. A. Calero and R. Marce, Mater. Sci. Eng. A 335 (2002) 1-5.

[14] J. Abenojar, F. Velasco, A. Bautista, M. Campos, J. A. Bas and J. M. Torralba, Compos. Sci. Technol. 63 (2003) 69-79.

[15] F. Velasco, J. R. ibars, J, M. Ruiz-Román, J. M. TORRAlBA AND J. M. Ruiz-PRIETO, Corrosion 52 (1996) 47-52.

[16] A. Bautista, F. Velasco, J. Abenojar and N. ANTÓN, $178^{\text {th }}$ Meeting of the Electrochemical Society, Abstracts vol. 2000-2, Ed. Electrochemical Society, Phoenix, USA, 2000, paper $n^{\circ}$ 387.

[17] J. A. González, E. Escudero, V. López, J. Simancas And M. Morcillo, Rev. Metal. Madrid 40 (2004) 259-269.

[18] J. A. González, E. Escudero, V. López, J. Simancas AND M. Morcillo, Rev. Metal. Madrid 40 (2004) 270-279.

[19] A. Pardo, M. C. Merino, J. Botella, V. Matres, F. Viejo, M. Carboneras and R. Arrabal, Rev. Metal. Madrid 40 (2004) 335-340.

[20] A. SALAK, Ferrous Powder Metallurgy, Ed. Cambridge International Science Publishing, Cambridge, UK, 1995, pp. 180-181.

[21] G. Lei, R. German and H. S. Nayar, Progr. Powder Metall. 39 (1984) 391-410. 